\title{
Exposure to solar radiation drives organismal vulnerability to climate: evidence from an intertidal limpet
}

\author{
Chapperon Coraline ${ }^{1,{ }^{*}}$, Volkenborn Nils ${ }^{2}$, Clavier Jacques ${ }^{1}$, Séité Sarah ${ }^{1}$, Seabra Rui ${ }^{3,4}$, \\ Lima Fernando P. ${ }^{3}$
}

\author{
${ }^{1}$ School of Biological Sciences, Flinders University, GPO Box 2100, Adelaide SA 5001, Australia \\ 2 Ifremer, DYNECO Laboratoire d'Ecologie Benthique, Plouzané 29280, France \\ ${ }^{3} \mathrm{CIBIO} / \mathrm{InBIO}$, Centro de Investigação em Biodiversidade e Recursos Genéticos, Universidade do \\ Porto, Campus Agrário de Vairão, 4485-661, Vairão, Portugal \\ ${ }^{4}$ Departamento de Biologia, Faculdade de Ciências da Universidade do Porto, R. Campo Alegre, s/n, \\ 4169-007, Porto, Portugal \\ *Corresponding author : Coraline Chapperon, email address : coralinechapperon@gmail.com
}

\begin{abstract}
:
Understanding the physiological abilities of organisms to cope with heat stress is critical for predictions of species' distributions in response to climate change. We investigated physiological responses (respiration and heart beat rate) of the ectotherm limpet Patella vulgata to heat stress events during emersion and the role of seasonal and microclimatic acclimatization for individual thermal tolerance limits. Individuals were collected from 5 microhabitats characterized by different exposure to solar radiation in the high intertidal zone of a semi-exposed rocky shore in winter and summer of 2014. Upper thermal tolerance limits (heat coma temperatures - HCTs, and heart rate Arrhenius break temperatures $A B T \mathrm{~s}$ ) were determined for individuals from each microhabitat in both seasons under laboratory conditions. While we found a clear seasonal acclimatization, i.e., higher HCTs and ABTs in summer than in winter, we did not find evidence for microhabitat-specific responses that would suggest microclimatic acclimatization. However, operative limpet temperatures derived from in-situ temperature measurements suggest that individuals from sun exposed microhabitats have a much narrower thermal safety margins than those from less exposed surfaces or within crevices. Microhabitat specific thermal safety margins caused by high thermal heterogeneity at small spatial scales and the lack of short term acclimatization will likely shape small scale distribution patterns of intertidal species in response to the predicted increase in the frequency and intensity of heat waves.
\end{abstract}




\section{Highlights}

1. Limpet thermal sensitivities and limits were investigated during emersion heat stress. 2. Seasonal and microclimatic acclimatization for thermal tolerance limits were examined. $\mathbf{3}$. Limpets showed seasonal acclimatization but a lack of microclimatic acclimatization. 4. Narrower thermal safety margins were observed on sun exposed surfaces. $\mathbf{5}$. Thermal heterogeneity at microscale will likely shape future distribution patterns.

Keywords : Patella vulgata, heat stress, acclimatization, thermal tolerance, microhabitat, intertidal 


\section{Introduction}

Climate-related changes in species' distributions have already been observed in benthic systems (Birchenough et al 2015). Predicting future species distributions and biodiversity patterns in a changing climate has become a priority over the last decades (Borja 2014) in order to anticipate the ecological and socio-economic impacts of climate related changes on local biodiversity (Sarà et al 2014). Therefore, knowledge on the physiological abilities of ectotherms in response to changes in temperature is critical (Bozinovic et al 2011). Organismal physiological performance and fitness affect population dynamics, species interaction and ecosystem functioning and are driven by the local environmental context (Doney et al 2012). For instance, intertidal invertebrates face high spatial and temporal temperature heterogeneities caused by exposure to water and air over the tidal cycle, and microhabitat-specific exposure to solar radiation in different seasons (Chapperon \& Seuront 2011, Seabra et al 2011). The microtopography of rocky substrates strongly influences the degree of exposure to solar radiation and shapes the variability in substrate temperature observed over the tidal cycle and in different seasons (Harley 2008, Miller et al. 2009, Seabra et al 2011).

Here we investigate whether microhabitat- and season-specific thermal histories of the limpet Patella vulgata affect its physiological ability to cope with sublethal thermal stress during emersion. Specifically, we examine the physiological responses of $P$. vulgata (respiration and cardiac activity) to heat stress in the laboratory and derived thermal safety margins for five microhabitats characterized by contrasting exposure to solar radiation. We hypothesize that both microhabitat (short-term) and seasonal (long-term) thermal acclimatization in $P$. vulgata affect its thermal tolerance limits and physiological performance in response to heat stress. In particular, we expect individuals from microhabitats characterized by large daily temperature variations to show a greater ability to 


\section{ACCEPTED MANUSCRIPT}

cope with thermal stress than individuals from microhabitats with more stable thermal conditions (Magozzi \& Calosi 2014). Similarly, we anticipate seasonal variations in the thermal sensitivities and thermal tolerance limits of limpets (i.e., we expect summer-adapted individuals to show a greater capacity to cope with heat stress than winter-adapted individuals, Davies 1965).

\section{Materials and Methods}

\subsection{Sampling site}

Individuals of $P$. vulgata were collected from a semi-exposed rocky shore (Dellec, Plouzané, France, $48^{\circ} 21^{\prime} 09^{\prime}$ 'N $4^{\circ} 34^{\prime} 01^{\prime}$ 'W) in winter and summer 2014 during daytime ebbing low tide. At the study site, $P$. vulgata occurred at densities of $135 \pm 18$ individuals $/ \mathrm{m}^{2}$. Since one of the objectives was to examine the effect of the recent thermal history on physiological responses to heat stress during emersion, individuals were collected one day before laboratory measurements to avoid acclimation to laboratory conditions. Adult P. vulgata belonging to a similar size class (with average height and length of ca. $15 \mathrm{~mm}$ and $32 \mathrm{~mm}$ ) were collected at the upper limit of their intertidal distribution where they experience the greatest temperature variations (Seabra et al 2011). Limpets were collected from five microhabitats characterized by different levels of exposure to solar radiation and thus potential differences in thermal stress: crevices ( $\mathrm{C}$, very low exposure), vertical north exposed (NE, low exposure), vertical west exposed (WE, high exposure), flat rock (FR, higher exposure) and vertical south exposed surfaces (SE, highest exposure).

Intertidal ectotherms' body temperatures are not correlated to the air temperature as they are affected by multiple interactive abiotic factors such as exposure to solar radiation, wind chill and wave splash (Helmuth \& Hofmann 2001; Fitzhenry et al. 2004; Broitman et al. 2009). Body temperatures also depend on morphological properties like shell shape and 


\section{ACCEPTED MANUSCRIPT}

color. To account for the influence of this suite of environmental and morphological factors on operative body temperatures, we deployed biomimetic loggers (robolimpets, Lima \& Wethey 2009) adjacent to substrate temperature loggers (iButton thermochron DS1921G-F5, Homechip UK). Temperature loggers were significantly correlated to robolimpets across all microhabitats $\left(\mathrm{R}^{2}>0.95, p<0.05\right.$; see Fig. 1 in supplementary materials as an example) and had an average bias of $1.25^{\circ} \mathrm{C}$ and a mean square error of $1.33{ }^{\circ} \mathrm{C}$. Due to logistic reasons, robolimpets were not deployed in all microhabitats and seasons. Instead, DS1922L iButton loggers were attached to the rocky substrate in each microhabitat using glazing tapes (Hodgson Sealants, UK) and temperature measurements were taken every 10 minutes over 14 days in both seasons. Note that summer recordings were conducted in September 2014 which was the month with the highest average daily maximum temperature for the period 20112014 as evidenced by data collected using biomimetic loggers at a shore less than $50 \mathrm{~km}$ away from our study site (see Fig. 2 in supplementary materials). Operative limpets temperatures were thus estimated using the equations of the significant linear relationships obtained between robolimpets and ibuttons temperature in the different microhabitats (estimated operative limpet temperature hereafter).

\subsection{Laboratory experiments}

We assessed three descriptors of thermal tolerance during emersion: heat coma temperature, Arrhenius break temperature and thermal safety margin (HCT, ABT and TSM, respectively; see Table 1 for definitions).

Upon collection, individuals were brought to the laboratory within 30 minutes and placed into a tank with natural tidal cycle and 12 hour photoperiod. Shells were scraped and carefully cleaned with ethanol to remove epibionts. To assess $H C T$, individuals were directly placed on the vertical walls of two cubic transparent plastic tanks (13 $\mathrm{cm}$ side). For combined 


\section{ACCEPTED MANUSCRIPT}

respiration and heart beat rate measurements or heart beat rate measurements only, limpets were positioned on horizontal sandstone plates after gluing heart beat infrared sensors onto their shells. Animals were sprayed with seawater to allow replenishment of mantle water and attachment to their support (Williams et al 2005). Seawater temperature was similar to that experienced by individuals at the collection site during immersion $\left(10^{\circ} \mathrm{C}\right.$ in winter and and $16{ }^{\circ} \mathrm{C}$ in summer). Room temperature was maintained to that of the seawater.

In all experiments, thermal stress during emersion was simulated by immersing containers (tanks or respirometry bottles without any water depending on experiments) within a thermostated water bath (Huber, Cryo-Polystat CC $-20 / 200^{\circ} \mathrm{C} 12 \mathrm{~L}$, Avantec, France). Two similar thermal ramps were used in this study, both featuring a warming rate of $6{ }^{\circ} \mathrm{C} /$ hour. However, for respiration and cardiac rate measurements, the water bath temperature was instantaneously raised $6{ }^{\circ} \mathrm{C}$ at the beginning of each hour, and kept constant until the next hour. On the other hand, on heat coma experiments and heart rate measurements, water bath temperature was raised using a smoother ramp of $1^{\circ} \mathrm{C}$ every 10 minutes (i.e., each target temperature was held for ca. 10 minutes). Data loggers (DS1921G-F5 iButton thermochron, Homechip UK) were placed inside each tank (three per tank) and each bottle (one per bottle) to confirm that water bath temperature and the temperature inside each tank were similar. An absorbent tissue saturated with seawater was placed in each tank/bottle to maintain $100 \%$ humidity level.

\subsubsection{Upper critical thermal limit measurement}

Upper thermal tolerance limits were determined by assessing HCTs. In this study, thermal coma was defined sensu stricto as the absence of physical response following stimuli - i.e. by pricking the foot and tentacles with a needle (Evans 1948). HCTs were determined by using the smoother temperature ramp $\left(1^{\circ} \mathrm{C} / 10\right.$ minutes $)$ and registering the temperature at which 


\section{ACCEPTED MANUSCRIPT}

animals started to detach from the container walls and failed to retract their foot and tentacles when gently stimulated with a needle (Clarke et al 2000a,b). After reaching HCTs, individuals were placed inside the tidal tank at field temperature and their survival was checked after 24 hours. Individuals detached from the substratum and not responding to any stimuli were considered dead. Since we were interested in heat coma temperatures and not lethal temperatures, data from dead individuals were discarded from the analyses. HCTs were estimated for individuals from each microhabitat in both seasons as the arithmetic mean of the temperatures at which individuals reached the endpoint $(n=22$ per microhabitat, experiments repeated twice in each season).

\subsubsection{Respiration and cardiac activity measurements}

Simultaneous monitoring of cardiac activity and respiration were used to measure metabolic responses of limpets to heat stress. Heart beat frequencies were measured with infrared sensors that enable non-invasive measurements of heart beats through the shells (Burnett et al 2013). On the day of each experiment, individuals were equipped with IR sensors $(n=5$; one individual per microhabitat) and moved into airtight $500 \mathrm{ml}$ plastic bottles adapted to allow the simultaneous measurements of respiration $\left(\mathrm{CO}_{2}\right.$ production) and cardiac activity. Experiments were repeated four times in winter and five times in summer. Plastic bottles were immersed in the thermostated water bath at field water temperature $\left(10^{\circ} \mathrm{C}\right.$ in winter, 16 ${ }^{\circ} \mathrm{C}$ in summer). Individuals were moved with their sandstone plates into bottles to minimize handling stress before the start of the experiment. As explained above, water bath temperature was instantaneously increased $6{ }^{\circ} \mathrm{C}$ at the beginning of each hour from $10{ }^{\circ} \mathrm{C}$ (winter) or $16{ }^{\circ} \mathrm{C}$ (summer) until a target temperature of $43{ }^{\circ} \mathrm{C}$ was reached. Respiration measurements were taken in each bottle successively after 20 min of acclimation to the target temperature. Bottles were connected to a closed circulation system with an integrated infrared 


\section{ACCEPTED MANUSCRIPT}

$\mathrm{CO}_{2}$ analyser (Li-Cor, Li-820) and a desiccation column filled with anhydrous calcium sulphate (Drierite, Xenia, USA). An adjustable pump maintained air flow at 0.8-0.9 $\mathrm{L} \mathrm{min}^{-1}$. $\mathrm{CO}_{2}$ partial pressure $\left(\mathrm{pCO}_{2}\right.$, in ppm: parts per million) in each bottle was recorded using the Li-820 software. $\mathrm{pCO}_{2}$ was measured every 5 seconds over a 3 minute period (Tagliarolo et al 2013). Respiration rates within each bottle were estimated by determining the linear slope of $\mathrm{pCO}_{2}$ over time (see Fig. 3 in supplementary materials). Cardiac activity was recorded every 10 minutes for 60 seconds during the whole thermal ramping essay. At each temperature along the thermal $\operatorname{ramp}\left(10^{\circ} \mathrm{C}\right.$ and/or $\left.16{ }^{\circ} \mathrm{C}, 22{ }^{\circ} \mathrm{C}, 28{ }^{\circ} \mathrm{C}, 34{ }^{\circ} \mathrm{C}, 40{ }^{\circ} \mathrm{C}, 43{ }^{\circ} \mathrm{C}\right)$, variations in $\mathrm{pCO}_{2}$ were measured within each bottle successively, with a pause of several minutes between measurements to stabilize the system. An entire cycle of respiration measurements lasted ca. 30 min. Preliminary measurements were conducted with empty bottles over the same thermal ramp and $\mathrm{pCO}_{2}$ variations were negligible in comparison to $\mathrm{pCO}_{2}$ increases in the presence of individual limpets. Fluxes of $\mathrm{pCO} 2$ were corrected for the net volume of the system and incubation time and normalized to biomass $\left(\mu \mathrm{mol} \mathrm{CO}_{2}\right.$ $\mathrm{gAFDW}^{-1} \mathrm{~h}^{-1}$ ). Individual biomass was estimated as ash-free dry weight (AFDW) through loss on ignition $\left(60^{\circ} \mathrm{C}\right.$ for $48 \mathrm{~h}$ for drying and $450^{\circ} \mathrm{C}$ for $4 \mathrm{~h}$ for burning).

\subsubsection{Arrhenius breakpoint measurements for cardiac activity}

$A B T$ was calculated for each microhabitat/season combination. Individuals fitted with heart beat sensors were exposed to a step-wise ramp of $1{ }^{\circ} \mathrm{C}$ every 10 minutes, from $10^{\circ} \mathrm{C}$ (winter) or $16{ }^{\circ} \mathrm{C}$ (summer) up to $43{ }^{\circ} \mathrm{C}$ or until heart beat was lost). Animals were kept on sandstone plates inside cubic plastic tanks ( $13 \mathrm{~cm}$ side) partially submerged in a water bath. $A B T \mathrm{~s}$ were

calculated as the temperature corresponding to the intersection point of the two best fitting lines on each side of the Arrhenius plots (Stillman \& Somero 1996). 


\subsection{Statistical analyses}

The distributions of thermal physiological descriptors (Table 1) at both seasons and in the different microhabitats were checked for normality using the Kolmogorov-Smirnov test. Levene's test was used to test for equality of variances. When data were normally distributed, a two-factor analysis of variance was used to determine the effects of season, and microhabitat on respiration, heart beat rate and Arrhenius break temperature. The effects of temperature upon both respiration and cardiac rates were assessed using repeated measures ANOVA with a Greenhouse-Geisser Correction since the data violated the assumption of sphericity (Mauchly's test of sphericity). Post hoc tests incorporating the Bonferroni correction were done to distinguish differences in respiration and heart rates between temperatures. When data failed normality even after log transformation, the non-parametric Mann-Whitney U-test (MW test hereafter) was used to compare heat coma temperatures between seasons. Similarly, the Kruskall Wallis Test (KW test hereafter) followed by subsequent non-parametric post hoc analyses (based on the Tukey test; Zar 2010) were used to compare heat coma temperatures and thermal safety margins between individuals collected within different microhabitats. All statistical analyses were carried out using PASW STATISTICS 18 (SPSS Inc., 2009, Chicago, IL, USA).

\section{Results}

\subsection{Estimated operative temperatures of Patella vulgata}

From the 10 deployed temperature data loggers ( 2 per microhabitat), 8 and 7 provided reliable data in winter and summer, respectively. In both seasons, minimal variations in estimated operative limpet temperatures were observed in microhabitats least exposed to solar radiation, whilst maximal thermal variations occurred on the sun exposed surfaces 


\section{ACCEPTED MANUSCRIPT}

(Table 2). In addition, during diurnal low tides, maximum estimated operative limpet temperatures and temperature variability were obtained on surfaces directly exposed to solar radiations (Figs. 1, 2). In contrast, estimated operative limpet temperatures within crevices and on north exposed rocks were much less variable in both seasons (Figs. 1, 2).

\subsection{Seasonal effect upon Patella vulgata thermal sensitivity and limits}

In both seasons, respiration and cardiac rates were significantly affected by temperature (Table 3). In winter, respiration rates increased from $16{ }^{\circ} \mathrm{C}$ to $28^{\circ} \mathrm{C}$ and then stabilized until the end of the thermal ramp (Table 3, Fig. 3). In winter, cardiac activity significantly increased from $10{ }^{\circ} \mathrm{C}$ to peak at $34{ }^{\circ} \mathrm{C}$ and then slowed down to almost acardia at $43{ }^{\circ} \mathrm{C}$ (Fig. 3). In summer, respiration rates were significantly lower at $16{ }^{\circ} \mathrm{C}$ than any other temperature (except $22{ }^{\circ} \mathrm{C}$ ). Respiration rates were mostly stable over the range $22-43{ }^{\circ} \mathrm{C}$ (but see significant differences in Table 3). Heart beat rate increased from $16{ }^{\circ} \mathrm{C}$ to $34{ }^{\circ} \mathrm{C}$ (Fig. 3) but no significant difference in heart beat rate was registered over the range $34-43{ }^{\circ} \mathrm{C}$ (Table 3 ).

The two-factorial analysis of variance revealed a significant seasonal effect on (i) heart beat rate $(\mathrm{p}<0.01$, Table 4$)$ at different temperature along the thermal ramp (but not on respiration rate, $\mathrm{p}>0.05$, Table 5) and also on (ii) $A B T$ values $(\mathrm{F}=19.373, \mathrm{df}=1, \mathrm{p}<0.001)$. More specifically, heart rate was higher in winter than in summer at all temperatures between $16{ }^{\circ} \mathrm{C}$ and $34{ }^{\circ} \mathrm{C}$, and at $43{ }^{\circ} \mathrm{C}(\mathrm{p}<0.05) . A B T$ s were higher in summer than in winter (Table 6, Fig. 4). Similarly, heat coma temperatures (HCTs) were significantly higher in summer $\left(42.5 \pm 0.1{ }^{\circ} \mathrm{C}\right)$ than in winter $\left(38.2 \pm 0.1^{\circ} \mathrm{C} ; M W\right.$ test, $\mathrm{Z}=-16.067, \mathrm{p}<0.001$; Fig. 5).

3.3. Microhabitat effect upon Patella vulgata thermal sensitivity and limits 


\section{ACCEPTED MANUSCRIPT}

The two-factorial analysis of variance revealed no significant effect of microhabitat upon respiration and cardiac rates along the thermal ramp (Tables 4,5$)$, and upon $A B T \mathrm{~s}(\mathrm{~F}=0.390$, $\mathrm{df}=4, \mathrm{p}=0.390)$

$H C T$ s were significantly higher in organisms collected on flat rocks than in individuals collected in any other microhabitat in winter (Tukey test following KW Test, $\mathrm{p}<0.05$, Fig. 5). In summer, the temperature at which heat coma was induced was significantly higher in individuals from vertical north- and south-faced surfaces than in animals from crevices and flat rock surfaces ( $p>0.05$, Fig. 5).

Thermal safety margins were significantly different between microhabitats $\left(\mathrm{KW}\right.$ test, $\chi^{2}=$ 186.231, df $=4, \mathrm{p}<0.01$, Fig. 6). On average, TSMs were significantly larger on individuals collected within crevices than on individuals from any other microhabitat (Fig. 6). TSMs of limpets from vertical west- and north-exposed microhabitats were significantly higher than those from flat and south exposed rocks (Fig. 6). The greatest $\operatorname{TSM}\left(22.5^{\circ} \mathrm{C}\right)$ was observed in an individual collected within a crevice whilst the smallest TSM was recorded on vertically south-faced substrate $\left(0.6^{\circ} \mathrm{C}\right)$.

\section{Discussion}

4.1. Sun exposure as a driver of microscale heterogeneity in $P$. vulgata operative temperatures

Patella vulgata experiences largely different thermal variations and extremes in different microhabitats, specifically during daytime low tides. Individuals from sun exposed microhabitats like flat, or vertical west- and vertical south- exposed rocks face variations in body temperature of up to $20^{\circ} \mathrm{C}$ whilst emerged in summer (Figs. 1, 2). As shown for the limpet Lottia gigantea, intertidal organisms in sun exposed microhabitats frequently experience sublethal and sometimes lethal thermal stress (Miller et al. 2009). Crevices and 


\section{ACCEPTED MANUSCRIPT}

north-faced surfaces appear to be more stable microenvironments with much lower thermal fluctuations and maxima. This study thus reinforces the evidence that the amount of solar radiation received by intertidal ecotherms within microhabitats drives the mosaic patterns of body temperatures and thermal stress at the microscale (Marshall et al 2010, Lima et al 2015). The effect of sun exposure is such that body temperature variations between sun exposed and shaded microhabitats have been demonstrated to be greater than those observed between shore levels or between sites separated by hundreds of km (Seabra et al 2011).

Besides solar radiation exposure, other local factors such as wave splash and timing of low tides have been shown to drive counterintuitive patterns of invertebrate body temperatures (Helmuth et al 2006) and thermal tolerance may vary over the distribution range of a given species (Kuo \& Sanford 2009). Intra-specific variability in physiological and biochemical adaptations of marine ectotherms to thermal stress has also been documented for different shore levels according to the emersion gradient (Stirling 1982, Tomanek \& Somero 1999, Stillman \& Somero 1996, Davenport \& Davenport 2005, Stenseng et al 2005, Nguyen et al 2011, Prusina et al 2014). Similarly, previous studies have highlighted differences in the metabolic responses to heat stress of intertidal ectotherms from different microhabitats. For instance, the limpet Cellana tramoserica displays higher metabolic rate (oxygen consumption) in response to heat stress in stable environments (rock overhangs) than in variable microhabitats (exposed flat rock, Sinclair et al 2006).

\subsection{Lack of short term acclimatization in $P$. vulgata thermal sensitivities and tolerance} In this study, individuals did not show any difference in their respiratory or cardiac responses to heat stress, regardless of the extent of daily thermal fluctuations and the frequency of exposure to thermal extremes that the limpets had experienced within their microhabitats. We found some significant differences in the upper thermal limit (HCTs) between P. vulgata 


\section{ACCEPTED MANUSCRIPT}

from different microhabitats, but no clear pattern was detected that would suggest that the acclimatization to the microhabitat specific thermal conditions affects the limpets' ability to cope with heat stress. The lack of microhabitat specific response was confirmed by $A B T$ s for heart rates that did not significantly differ among individuals from different microhabitats. These results seem counterintuitive since reversible acclimatization should be an advantage in individuals experiencing diel temperature variations (Gabriel 2005, Young \& Gifford 2013). Nonetheless, others species such as the high shore snail Echinolittorina malaccana also show no significant differences in metabolic rate between sun-exposed and shaded microhabitats when facing heat stress (Marshall et al 2013). Besides the lack of short term acclimatization to surrounding microclimatic conditions, $P$. vulgata, as others ectothermic species, adapts its metabolism through thermal compensation (e.g. Marshall et al 2013). Even though the high coefficient of variations in respiratory rate $(25 \%$ to $67 \%$ in winter, and $43 \%$ to $63 \%$ in summer) is indicative of a high inter-individual variability, on average, respiration did not vary significantly in the range $22 / 28-43{ }^{\circ} \mathrm{C}$. This temperature-insensitive metabolism has previously been observed in terrestrial ectotherms like reptiles (Seebacher 2005) and marine invertebrates like the snails Littorina littorea during the whole resting state (Newell \& Pye 1970, 1971), E. malaccana (Marshall et al 2013) over a temperature range of $35-46{ }^{\circ} \mathrm{C}$, and the limpet Lottia digitalis over a temperature range of $15{ }^{\circ} \mathrm{C}$ to $35^{\circ} \mathrm{C}$ (Bjelde \& Todgdam 2013). Others Lottia limpets (L. scabra, L. austrodigitalis, L. limatula, L. pelta) increase their aerial respiration rate with increasing temperature up to a temperature threshold beyond which respiration decreases (Miller et al 2015). Nevertheless, these species also show some metabolic rate control over the range $20-30{ }^{\circ} \mathrm{C}\left(Q_{10}\right.$ values lower than 1.5 , Miller et al 2015). Although short-term metabolic compensation (maintenance of constant rate processes) is not universal (e.g. Bannister 1974), it is similarly to metabolism depression (decrease of metabolic rate below that of resting state), an adaptation strategy under environmental 


\section{ACCEPTED MANUSCRIPT}

(thermal) change. Both temperature-independent metabolism and hypometabolism allow ectotherms to minimize energy loss (energy conservation) and withstand higher temperatures for longer periods during aestivation (Guppy \& Withers 1999, Marshall et al 2011). The lack of shifts in thermal sensitivity between individuals from different microhabitats suggests that P. vulgata is a generalist species, metabolically adapted to the wide range of temperatures that it can potentially encounter in the different microhabitats on the upper intertidal zone. However, being generalist also means that individuals living on sun exposed surfaces are not better adapted to cope with the thermal extremes frequently reached in these microhabitats, as indicated by the lack of differences in their thermal tolerance parameters (HCTs and $A B T \mathrm{~s}$ ). This is not consistent with previous studies that indicated that the recent thermal history of individuals is the most influential factor determining thermal tolerance (Lutterschmidt \& Hutchison 1997, Clarke et al 2000a). Even though the temperature experienced in the field during the studied period never surpassed that of the HCTs obtained in laboratory, some south exposed individuals had a very narrow thermal safety margin $\left(0.6^{\circ} \mathrm{C}\right)$. Limpets on south faced surfaces seem particularly vulnerable since the maximal temperature experienced in the field in summer during the study period $\left(40.4^{\circ} \mathrm{C}\right)$ exceeded that of the $A B T$ s calculated based on our laboratory results. Other ectothermic species have shown an absence of microhabitat acclimatization regarding their upper thermal limits. Instead they displayed different responses to heat stress at the molecular and cellular levels. For instance, despite the lack of local adaptation in a physiological parameters (critical thermal maximum, $C T_{\max }$ ), coastal crabs exhibited a higher production of heat shock proteins (Hsp70) in comparison with estuarine crabs (Madeira et al 2012). These differences were associated with differences in local temperatures and air humidity (Madeira et al 2012). Similarly, shrimp in the upper intertidal showed higher production of Hsp70 and total ubiquitin and histopathological alterations than shrimp from the lower intertidal despite an absence of differences in $C T_{\max }$ 


\section{ACCEPTED MANUSCRIPT}

(Madeira et al 2015). These studies stress the need to further investigate the heat stress response of $P$. vulgata at the molecular level, as the patterns of variations of stress proteins have been shown to occur even within small-scale thermal mosaics (Hofmann 1999).

\subsection{Seasonal acclimatization in $P$. vulgata thermal sensitivities and tolerance}

Even though the daily temperature variations at our study site were large, perhaps the unpredictability of the frequency of occurrence of heat stress events could have led to the absence of short term acclimatization of HCTs and ABTs (Clarke et al 2000a). Indeed, even if acclimatization can occur over a few weeks (mitochondrial function) or days (cardiovascular function), the energy spent to increase $A B T \mathrm{~s}$ and $H C T$ s to maintain organismal homeostasis under stochastic events such as heat waves is potentially too high, outweighing its long term benefits. Another explanation is that diel variations in temperature at the study site were not high enough in comparison with long term thermal variations. This hypothesis is compatible with our results that clearly indicate seasonal acclimatization of heart beat rate i.e. cardiac activity was lower in winter than in summer at all temperatures (except at $40^{\circ} \mathrm{C}$ ) and heart beat rate peaked at a lower temperature in winter than in summer. Similarly, the greater $A B T \mathrm{~s}$ and $H C T$ s in summer are indicative of seasonal acclimatization of the thermal tolerance for cardiac function and upper limit. Evidence of seasonal acclimatization in cardiac responses to heat stress and thermal tolerance is common in the literature. For instance, the limpet Lottia limatula (Segal 1956), the pond snail Lymnaea stagnalis (Harrison 1977) and the crab Pachygraspsus marmoratus (De Pirro et al 1999) all show greater heart rate in winter than in summer at corresponding temperatures. The temperature for peak heart rate in L. stagnalis (Harrison 1977) was also found to be lower in winter $\left(30.5^{\circ} \mathrm{C}\right)$ than in summer $\left(37.5^{\circ} \mathrm{C}\right)$. Seasonal acclimatization of the cardiac function allows individuals to be more tolerant to higher temperatures in the warm months. 


\section{ACCEPTED MANUSCRIPT}

As with other ectotherms such as the freshwater mussel Unio tumidus, there was no seasonal acclimatization in respiratory rates (Lurman et al 2014), but we previously discussed an alternative strategy used by $P$. vulgata to cope with thermal stress, i.e. thermal insensitive metabolism. In summer, the higher upper thermal tolerance limits $\left(H C T \mathrm{~s}, 42.5 \pm 0.1{ }^{\circ} \mathrm{C}\right.$ as compared to $38.2 \pm 0.1{ }^{\circ} \mathrm{C}$ in winter) and thermal tolerance limits of heart function $(A B T \mathrm{~s}$, $36.9 \pm 0.3^{\circ} \mathrm{C}$ instead of $34.3 \pm 0.6^{\circ} \mathrm{C}$ in winter) most certainly facilitate $P$. vulgata's ability to cope with temperature extremes and higher sublethal thermal stress experienced in the upper intertidal zone. Although this intra-individual flexibility in shifting upper thermal limits over extended periods of time may constitute an adaptive strategy in a warming climate, this study also reveals that not all individuals within the same shore level are equal in terms of vulnerability to future warming.

4.4. Not all vulnerable to the warming climate: the importance of microscale heterogeneity High shore ectotherms are generally assumed to be particularly vulnerable to the predicted increase in the frequency and intensity of heat events (Planton et al 2008) as they often live at or close to their upper thermal tolerance limits (Somero 2002). However, our results highlight that not all high shore limpets are threatened by further warming and heat events. Since individuals of $P$. vulgata do not appear to show any acclimatization ability in their thermal tolerance and sensitivity as a function of their surrounding microclimatic conditions, those living on south-exposed and flat rocks seem to be highly vulnerable to extreme heat events with current TSMs (based on our 14 day-long thermal recordings) ranging from $3.3{ }^{\circ} \mathrm{C}$ to 9.3 ${ }^{\circ} \mathrm{C}$, and $0.6{ }^{\circ} \mathrm{C}$ to $5{ }^{\circ} \mathrm{C}$, respectively. At the opposite, organisms on vertical north- and vertical west-exposed rocky walls display a $T S M$ of ca. $17^{\circ} \mathrm{C} . T S M$ is even higher within crevices, exceeding $20{ }^{\circ} \mathrm{C}$. This is consistent with a previous study that highlighted differences in safety margin between shade-resting and sun exposed E. malacanna snails 


\section{ACCEPTED MANUSCRIPT}

(Marshall et al 2013). The tropical freshwater snail Clea nigricans also showed much higher thermal safety margin than expected (Polgar et al 2015). These results show the need to investigate the impact of thermal heterogeneity on the patterns of thermal tolerance within populations at the microscale.

\section{Conclusion}

This study emphasizes the importance of accounting for acclimatization ability, thermal sensitivity, tolerance and limitations imposed by short- and long-term temperature variability in climate change studies. In a scenario of warming climate, thermal heterogeneity at the microscale will probably create "losers" and "winers" among individuals of a given species, and will likely shape abundance patterns of local populations and thus geographic ranges of species. This study demonstrated that sun exposed limpets frequently face temperatures which can be higher than the $A B T$ and very close to the $H C T$ during summer low tides. Living under prolonged sublethal thermal conditions during emersion is energetically costly and can impact the bioenergetic budget and thus the performance (growth, reproduction, foraging ability, Pörtner et al 2006) and fitness (Somero 2002, 2010) of these organisms. This indicates that $P$. vulgata may narrow its high shore distribution to shaded microhabitats or surfaces characterized by low exposure to solar radiations in the future climate (see also Lima et al 2015). Further studies are required to investigate the potential buffering effect of thermoregulatory behaviours (e.g. shell raising Williams et al 2005). These behavioral strategies could potentially alleviate the bioenergetics cost of living in a thermally stressful environment by reducing the exposure to temperatures capable of inducing cardiac failure and entry into heat coma (Marshall et al 2013). P. vulgata has previously been shown to keep faithful to its home scar (Lima et al 2015) during the hottest periods of the day, and therefore individuals do not relocate to a less stressful microhabitat in case of heat stress. Recent field investigation has instead shown that $P$. vulgata can raise its shell to significantly lower its 


\section{ACCEPTED MANUSCRIPT}

body temperatures in comparison to surrounding substrate temperature during heat stress maintaining body temperature at a maximum of $40^{\circ} \mathrm{C}$ (maximal temperature inducing cardiac failure in the present study) whilst substrate temperature could reach $42^{\circ} \mathrm{C}$ (C. Chapperon, unpub. data). Therefore, studies integrating thermal dependent physiology, behavior, and biochemical responses at the molecular level are highly needed for a mechanistic understanding of heat stress responses in ectotherms and to predict their vulnerability and distribution patterns in the warming climate.

\section{Acknowledgements}

The authors thank L. Seuront for useful discussion regarding methodology, J. Grall for field prospection and C. Moreira for her help with the deployment of robolimpets. We acknowledge three anonymous reviewers for their critical comments and suggestions that greatly improved an earlier version of this work. This work was supported by the "Laboratoire d'Excellence" LabexMER (ANR-10-LABX-19) and co-funded by a grant from the French government under the program "Investissements d'Avenir", and by a grant from the Regional Council of Brittany (SAD programme). F. P. Lima and R. Seabra were funded by FEDER (FCOMP-01-0124-FEDER-010564, FCOMP-01-0124-FEDER-020817) and FCT (PTDC/MAR/099391/2008, PTDC/MAR/117568/2010, SFRH/BD/68521/2010 and IF/00043/2012).

\section{References}

Bannister JV (1974) The respiration in air and in water of the limpets Patella caerulea (L.) and Patella lusitanica (Gmelin). Comparative Biochemistry and Physiology, 49A, 407411. 


\section{ACCEPTED MANUSCRIPT}

Birchenough SNR, Reiss H, Degraer S, Mieszkowska N, Borja Á, Buhl-Mortensen L, Braechman U, Craeymeersch J, De Mesel I, Kerckhof F, Krönche I, Parra S, Rabaut M, Schröder A, Van Colen C, Van Hoey G, Vinc M, Wätjen K (2015). Climate change and marine benthos: a review of existing research and future directions in the North Atlantic. Wiley interdisciplinary reviews: climate change, 6(2), 203-223.

Bjelde BE, Todgham AE (2013). Thermal physiology of the fingered limpet Lottia digitalis under emersion and immersion. The Journal of Experimental Biology, 216(15), 28582869.

Borja A (2014). Grand challenges in marine ecosystems ecology. Frontiers in Marine Science, 1, DOI=10.3389/fmars.2014.00001.

Bozinovic F, Calosi P, Spicer JI (2011). Physiological correlates of geographic range in animals. Annual Review of Ecology, Evolution, and Systematics, 42, 155-179.

Broitman BR, Szathmary PL, Mislan KAS, Blanchette CA Helmuth B (2009). Predator-prey interactions under climate change: the importance of habitat vs. body temperature. Oikos, 118 (2), 219-224.

Burnett NP, Seabra R, de Pirro M, Wethey DS, Woodin SA, Helmuth B, Zippay ML, Sarà G, Monaco C, Lima FP (2013). An improved noninvasive method for measuring heartbeat of intertidal animals. Limnology and Oceanography ,11(2), 91-100.

Chapperon C, Seuront L (2011). Space-time variability in environmental thermal properties and snail thermoregulatory behaviour. Functional Ecology, 25, 1040-1050.

Clarke AP, Mill PJ, Grahame J (2000a). The nature of heat coma in Littorina littorea (Mollusca: Gastropoda). Marine Biology, 137(3), 447-451.

Clarke AP, Mill PJ, Grahame J (2000b). Biodiversity in Littorina species (Mollusca: Gastropoda): a physiological approach using heat-coma. Marine Biology, 137(3), 559-565. 


\section{ACCEPTED MANUSCRIPT}

Davenport J, Davenport JL (2005). Effects of shore height, wave exposure and geographical distance on thermal niche width of intertidal fauna. Marine Ecology Progress Series, 292, 41-50.

Davies PS (1965). Environmental acclimation in the limpet Patella vulgata L. Nature, 205, 924.

De Pirro M, Cannicci S, Santini G (1999). A Multi-factorial experiment on heart rate variations in the intertidal crab Pachygraspsus marmoratus. Marine Biology, 135, 341345.

Doney SC, Ruckelshaus M, Duffy JE, Barry JP, Chan F, English CA, Glaindo HM, Grebmeier JM, Hollowed AB, Knowlton N, Polovina J, Rabalais NN, Sydeman WJ, Talley LD (2012). Climate change impacts on marine ecosystems. Marine Science, 4, 11 37.

Evans RG (1948). The lethal temperatures of some common British littoral molluscs. The Journal of Animal Ecology, 17(2), 165-173.

Fitzhenry T, Halpin PM, Helmuth B (2004). Testing the effects of wave exposure, site, and behaviour on intertidal mussel body temperatures: applications and limits of temperature logger design. Marine Biology, 145(2), 339-349.

Gabriel W (2005). How stress selects for reversible phenotypic plasticity. Journal of Evolutionary Biology, 18(4), 873-883.

Guppy M, Withers P (1999). Metabolic depression in animals: physiological perspectives and biochemical generalizations. Biological Reviews of the Cambridge Philosophical Society, 74(1), 1-40.

Harley CDG (2008). Tidal dynamics, topographic orientation, and temperature-mediated mass mortalities on rocky shores. Marine Ecology Progress Series, 371, 37-46. 


\section{ACCEPTED MANUSCRIPT}

Harrison PTC (1977). Seasonal changes in the heart rate of the freshwater pulmonate Lymnaea stagnalis (L.). Comparative Biochemistry and Physiology Part A: Physiology, 58A 37-41.

Helmuth BST, Hofmann GE (2001). Microhabitats, thermal heterogeneity, and patterns of physiological stress in the rocky intertidal zone. The Biological Bulletin, 201, 374-384.

Helmuth B, Broitman BR, Blanchette CA, Gilman S, Halpin P, Harley CDG, O’Donnell J, Hofmann GE, Menge B, Strickland D (2006). Mosaic patterns of thermal stress in the rocky intertidal zone: implications for climate change. Ecology Monographs, 76, 461-479.

Hofmann GE (1999). Ecologically relevant variation in induction and function of heat shock proteins in marine organisms. American Zoologist, 39(6), 889-900.

Kuo ESL, Sanford E (2009). Geographic variation in the upper thermal limits of an intertidal snail: implications for climate envelope models. Marine Ecology Progress Series, 388, 137-146.

Lima FP, Wethey DS (2009). Robolimpets: measuring intertidal body temperatures using biomimetic loggers. Limnology and Oceanography: Methods, 7(5), 347-353.

Lima FP, Gomes F, Seabra R, Wethey DS, Seabra I, Cruz T, Santos AM, Hilbish TJ (2015). Loss of thermal refugia near equatorial range limits. Global Change Biology, DOI: 10.1111/gcb.13115.

Lurman GJ, Walter J, Hoppeler HH (2014). The effect of seasonal temperature variation on behaviour and metabolism in the freshwater mussel (Unio tumidus). Journal of Thermal Biology, 43, 13-23.

Lutterschmidt WI, Hutchison VH (1997). The critical thermal maximum: history and critique. Canadian Journal of Zoology, 75(10), 1561-1574. 


\section{ACCEPTED MANUSCRIPT}

Madeira D, Narciso L, Cabral HN, Diniz MS, Vinagre C (2012). Thermal tolerance of the crab Pachygrapsus marmoratus: intraspecific differences at a physiological (CTMax) and molecular level (Hsp70). Cell Stress and Chaperones, 17(6), 707-716.

Madeira D, Mendonça V, Dias M, Roma J, Costa PM, Larguinho M, Vinagre C, Diniz MS (2015). Physiological, cellular and biochemical thermal stress response of intertidal shrimps with different vertical distributions: Palaemon elegans and Palaemon serratus. Comparative Biochemistry and Physiology Part A: Molecular \& Integrative Physiology, 183, 107-115.

Magozzi S, Calosi P (2014). Integrating metabolic performance, thermal tolerance, and plasticity enables for more accurate predictions on species vulnerability to acute and chronic effects of global warming. Global Change Biology, 21(1), 181-194.

Marshall DJ, McQuaid CD, Williams GA (2010). Non-climatic thermal adaptation: implications for species' responses to climate warming. Biology Letters, 6, 669-673.

Marshall DJ, Dong YW, McQuaid CD, Williams GA (2011). Thermal adaptation in the intertidal snail Echinolittorina malaccana contradicts current theory by revealing the crucial roles of resting metabolism. The Journal of Experimental Biology, 214(21), 36493657.

Marshall DJ, Baharuddin N, McQuaid CD (2013). Behaviour moderates climate warming vulnerability in high-rocky-shore snails: interactions of habitat use, energy consumption and environmental temperature. Marine Biology, 160(9), 2525-2530.

Miller LP, Harley CDG, Denny MW (2009). The role of temperature and desiccation stress in limiting the local-scale distribution of the owl limpet Lottia gigantea. Functional Ecology, 23(4), 756-767. 


\section{ACCEPTED MANUSCRIPT}

Miller LP, Allen BJ, King FA, Chilin DR, Reynoso VM, Denny MW (2015). Warm microhabitats drive both increased respiration and growth rates of intertidal consumers. Marine Ecology Progress Series, 522, 127-143.

Newell RC, Pye VI (1970). Seasonal changes in the effect of temperature on the oxygen consumption of the winkle Littorina littorea (L.) and the mussel Mytilus edulis L. Comparative Biochemistry and Physiology, 34(2), 367-383.

Newell RC, Pye VI (1971). Quantitative aspects of the relationship between metabolism and temperature in the winkle Littorina littorea (L.). Comparative Biochemistry and Physiology Part B: Comparative Biochemistry, 38(4), 635-650.

Nguyen KDT, Morley SA, Lai CH, Clark MS, Tan KS, Bates AE, Peck LS (2011). Upper temperature limits of tropical marine ectotherms: global warming implications. PLoS One, 6(12), e29340-e29340.

Planton S, Deque M, Chauvin F, Terray L (2008). Expected impacts of climate change on extreme climate events. Comptes Rendus Geosciences, 340, 564-574.

Polgar G, Khang TF, Chua T, Marshall DJ (2015). Gross mismatch between thermal tolerances and environmental temperatures in a tropical freshwater snail: Climate warming and evolutionary implications. Journal of Thermal Biology, 47, 99-108.

Pörtner HO, Bennett AF, Bozinovic F, Clarke A, Lardies MA, Lucassen M, Pelster B, Schiemer F, Stillman JH (2006). Trade-off in thermal adaptation: the need for a molecular to ecological interaction. Physiological and Biochemical Zoology, 79(2), 295-313.

Prusina I, Sarà G, De Pirro M, Dong YW, Han GD, Glamuzina B, Williams GA (2014). Variations in physiological responses to thermal stress in congeneric limpets in the Mediterranean Sea. Journal of Experimental Marine Biology and Ecology, 456, 34-40.

Sarà G, Milanese M, Prusina I, Sarà A, Angel DL, Glamuzina B, Nitzan T, Freeman S, Rinaldi A, Palmeri V, Montalto V, Lo Martire M, Gianguzza P, Arizza V, Lo Brutto S, De 


\section{ACCEPTED MANUSCRIPT}

Pirro M, Helmuth B, Murray J, De Cantis S, Williams GA (2014). The impact of climate change on Mediterranean intertidal communities: losses in coastal ecosystem integrity and services. Regional Environmental Change, 14(1), 5-17.

Seabra R, Wethey DS, Santos AM, Lima FP (2011). Side matters: microhabitat influence on intertidal heat stress over a large geographical scale. Journal of Experimental Marine Biology and Ecology, 400(1-2), 200-208.

Seebacher F (2005). A review of thermoregulation and physiological performance in reptiles: what is the role of phenotypic flexibility? Journal of Comparative Physiology B, 175(7), $453-461$.

Segal E (1956). Microgeographic variation as thermal acclimation in an intertidal mollusc. The Biological Bulletin, 111(1), 129-152.

Sinclair ELE, Thompson MB, Seebacher F (2006). Phenotypic flexibility in the metabolic response of the limpet Cellana tramoserica to thermally different microhabitats. Journal of Experimental Marine Biology and Ecology, 335(1), 131-141.

Somero GN (2002). Thermal physiology and vertical zonation of intertidal animals: optima, limits, and costs of living. Integrative and Comparative Biology, 42(4), 780-789.

Somero GN (2010). The physiology of climate change: how potentials for acclimatization and genetic adaptation will determine "winners" and "losers". The Journal of Experimental Biology, 213, 912-920.

Stenseng E, Braby CE, Somero GN (2005). Evolutionary and acclimation-induced variation in the thermal limits of heart function in congeneric marine snails (Genus Tegula): implications for vertical zonation. The Biological Bulletin, 208(2), 138-144.

Stillman J, Somero G (1996). Adaptation to temperature stress and aerial exposure in congeneric species of intertidal porcelain crabs (genus Petrolisthes): correlation of 


\section{ACCEPTED MANUSCRIPT}

physiology, biochemistry and morphology with vertical distribution. The Journal of Experimental Biology, 199(8), 1845-1855.

Stirling HP (1982). The upper temperature tolerance of prosobranch gastropods of rocky shores at Hong Kong and Dar Es Salaam, Tanzania. Journal of Experimental Marine Biology and Ecology, 63(2), 133-144.

Sunday JM, Bates AE, Kearney MR, Colwell RK, Dulvy NK, Longino JT, Huey RB (2014). Thermal-safety margins and the necessity of thermoregulatory behavior across latitude and elevation. Proceedings of the National Academy of Sciences of the United States of America, 111(15), 5610-5615.

Tagliarolo M, Grall J, Chauvaud L, Clavier J (2013). Aerial and underwater metabolism of Patella vulgata L.: comparison of three intertidal levels. Hydrobiologia, 702(1), 241-253.

Tomanek L, Somero GN (1999). Evolutionary and acclimation-induced variation in the heatshock responses of congeneric marine snails (genus Tegula) from different thermal habitats: implications for limits of thermotolerance and biogeography. The Journal of Experimental Biology, 202(21), 2925-2936.

Williams GA, De Pirro M, Leung KMY, Morritt D (2005). Physiological responses to heat stress on a tropical shore: the benefits of mushrooming behaviour in the limpet Cellana grata. Marine Ecology Progress Series, 292, 213-234.

Young VK, Gifford ME (2013). Limited capacity for acclimation of thermal physiology in a salamander, Desmognathus brimleyorum. Journal of Comparative Physiology B, 183(3), 409-418.

Zar JH (2010). Biostatistical analysis. Fifth Edition. Upper Saddle River NJ, Prentice hall. 


\section{ACCEPTED MANUSCRIPT}

\section{Table captions.}

Table 1. Definitions of thermal physiological descriptors used in the present study.

Table 2. Patella vulgata estimated operative temperature in winter and in summer 2014 on a semi exposed rocky shore (Dellec, $48^{\circ} 21^{\prime} 09 \mathrm{~N}, 4^{\circ} 34^{\prime} 01 \mathrm{~W}$, France) in different microhabitats (C: crevice; NE: vertical north exposed; WE: vertical west exposed; FR: flat rock; SE: vertical south exposed). $n=1990$ and $n=1988$ in all microhabitats in winter and summer respectively (except $\mathrm{n}=702$ in summer on vertical west-exposed surfaces).

Table 3. Repeated measures ANOVA with a Greenhouse-Geisser Correction followed by Post hoc tests using the Bonferroni correction to investigate differences in the respiratory and cardiac responses of Patella vulgata at different temperatures over a thermal ramp in the laboratory (increase in $6{ }^{\circ} \mathrm{C}$ increments) in both winter and summer.

Table 4. Two-factorial analysis of variance to investigate season, microhabitat and season $\times$ microhabitat effects upon cardiac rates of Patella vulgata at different temperatures along a thermal ramp in laboratory (increase in $6{ }^{\circ} \mathrm{C}$ increments).

Table 5. Two-factorial analysis of variance to investigate season, microhabitat and season $\times$ microhabitat effects upon respiration rates of Patella vulgata at different temperatures over a thermal ramp in laboratory (increase in $6^{\circ} \mathrm{C}$ increments).

Table 6. Arrhenius Break Temperatures of Patella vulgata heart rate obtained in individuals facing using a step-wise ramp of $1{ }^{\circ} \mathrm{C}$ every 10 minutes in laboratory in both winter and summer. Individuals were collected within different microhabitats $(\mathrm{C}$ : crevice; WE: vertical west exposed; NE: vertical north exposed; FR: flat rock; SE: vertical south exposed). 
Table 1.

Thermal

physiological Definition

descriptor

Temperature at which individuals became detached from support and did not show any response after pricking the foot and tentacles with a

Heat Coma needle (Evans 1948). Individuals showed a response to a test of

Temperature $(H C T)$ irritability after 24hours.

$H C T$ was used as a proxy for the critical thermal limit $\left(C T_{\max }\right)$ of locomotor performance (Polgar et al 2015)

Arrhenius Break Temperature above which heart beat rates decrease rapidly (Stillman Temperature (ABT) and Somero 1996), thus indicating cardiac function failure. margin (TSM)

the present study) and the maximal estimated operative temperature (Sunday et al 2014) recorded over a 14 days period in summer 2014 within each studied microhabitat. 
Table 2.

\begin{tabular}{|c|c|c|c|c|}
\hline Season & Microhabitat & Mean $( \pm$ SE) & Min-Max & Range \\
\hline \multirow{8}{*}{ Winter } & $C$ & $8.2(0.0)$ & $3.3-13.2$ & 9.9 \\
\hline & $N E 1$ & $8.9(0.0)$ & $5.5-12.3$ & 6.8 \\
\hline & $N E 2$ & $8.6(0.0)$ & $5.5-11.9$ & 6.4 \\
\hline & $W E$ & $8.5(0.0)$ & $4.2-13.7$ & 9.5 \\
\hline & $F R 1$ & $8.2(0.0)$ & $3.7-15.2$ & 11.4 \\
\hline & $F R 2$ & $8.1(0.0)$ & $3.3-13.7$ & 10.5 \\
\hline & $S E 1$ & $8.4(0.0)$ & $4.2-18$ & 13.8 \\
\hline & $S E 2$ & $8.5(0.0)$ & $4.7-19.5$ & 14.8 \\
\hline \multirow{7}{*}{ Summer } & $C$ & $18.2(0.0)$ & $15.7-21$ & 5.3 \\
\hline & $N E$ & $15.2(0.0)$ & $13.1-26.3$ & 13.2 \\
\hline & $W E$ & $17.0(0.1)$ & $14.2-29.5$ & 15.2 \\
\hline & FRl & $18.1(0.1)$ & $13.3-34.7$ & 21.4 \\
\hline & $F R 2$ & $18.0(0.1)$ & $13.7-34.2$ & 20.5 \\
\hline & $S E 1$ & $19.3(0.1)$ & $14.3-40.4$ & 26.2 \\
\hline & $S E 2$ & $20.3(0.2)$ & $14.2-39.0$ & 24.8 \\
\hline
\end{tabular}


Table 3.

$\begin{array}{llllll}\text { Season Parameter } d f s & F & P & \text { Post Hoc }\end{array}$

\begin{tabular}{|c|c|c|c|c|c|}
\hline \multirow[t]{2}{*}{ Winter } & Respiration & $\begin{array}{l}2.370 \\
37,919\end{array}$ & 55.967 & $\begin{array}{l}< \\
0.001\end{array}$ & $\begin{array}{l}10=16<22<28=34=40=43 ; 22= \\
43\end{array}$ \\
\hline & Heart rate & $\begin{array}{l}2.542 \\
45.757\end{array}$ & 69.888 & $\begin{array}{l}< \\
0.001\end{array}$ & $\begin{array}{l}10<16<22<28<34=40>43 \\
10=43 ; 22=40 ; 28=40\end{array}$ \\
\hline \multirow[t]{2}{*}{ Summer } & Respiration & $\begin{array}{l}2.246 \\
24.709\end{array}$ & 14.983 & $\begin{array}{l}< \\
0.001\end{array}$ & $\begin{array}{l}16=22=28=34=40=43 ; 16<28 \\
16<34 ; 16<40 ; 16<43 ; 22<40 ; 34 \\
>43\end{array}$ \\
\hline & Heart rate & $\begin{array}{l}2.495 \\
32.431\end{array}$ & 41.626 & $\begin{array}{l}< \\
0.001\end{array}$ & $16<22<28<34=40=43 ; 28=43$ \\
\hline
\end{tabular}

Table 4.

\begin{tabular}{|c|c|c|c|c|c|c|c|c|c|c|c|c|c|c|c|c|c|c|}
\hline $\begin{array}{l}\text { Cardi } \\
\text { ac } \\
\text { rate }\end{array}$ & & ${ }^{\circ} \mathbf{C}$ & & & & & $\begin{array}{l}2 \\
2^{\circ} \\
C\end{array}$ & & & $\begin{array}{l}2 \\
8^{\circ} \\
\mathrm{C}\end{array}$ & & & $\begin{array}{l}3 \\
4^{\circ} \\
C\end{array}$ & & & $\begin{array}{l}4 \\
0^{\circ} \\
\mathrm{C}\end{array}$ & & $\begin{array}{l}43 \\
{ }^{\circ} \mathrm{C}\end{array}$ \\
\hline $\begin{array}{l}\text { Treat } \\
\text { ment }\end{array}$ & $\begin{array}{l}d \\
f\end{array}$ & $F$ & $P$ & $\begin{array}{l}d \\
f\end{array}$ & $F$ & $\boldsymbol{P}$ & $d f$ & $F$ & $\boldsymbol{P}$ & $d f$ & $\boldsymbol{F}$ & $\boldsymbol{P}$ & $d f$ & $F$ & $\boldsymbol{P}$ & $d f$ & $\boldsymbol{F}$ & $\boldsymbol{P}$ \\
\hline $\begin{array}{l}\text { Micro } \\
\text { habit } \\
\text { at }\end{array}$ & 4 & $\begin{array}{l}1 . \\
44 \\
5\end{array}$ & $\begin{array}{l}0 . \\
24 \\
4\end{array}$ & 4 & $\begin{array}{l}1.4 \\
18\end{array}$ & $\begin{array}{l}0.2 \\
53\end{array}$ & 4 & $\begin{array}{l}1.7 \\
61\end{array}$ & $\begin{array}{l}0.1 \\
63\end{array}$ & 4 & $\begin{array}{l}0.2 \\
00\end{array}$ & $\begin{array}{l}0 . \\
93 \\
7\end{array}$ & 4 & $\begin{array}{l}0 . \\
69 \\
7\end{array}$ & $\begin{array}{l}0 . \\
60 \\
0\end{array}$ & 4 & $\begin{array}{l}2.0 \\
05\end{array}$ & $\begin{array}{l}0 . \\
11 \\
7\end{array}$ \\
\hline $\begin{array}{l}\text { Seaso } \\
\mathrm{n}\end{array}$ & 1 & $\begin{array}{l}8 . \\
91 \\
8 \\
\end{array}$ & $\begin{array}{l}<0 \\
.0 \\
1 \\
\end{array}$ & 1 & $\begin{array}{l}25 . \\
52 \\
7\end{array}$ & $\begin{array}{l}<0 \\
00 \\
1\end{array}$ & 1 & $\begin{array}{l}37 . \\
80 \\
6 \\
\end{array}$ & $\begin{array}{l}<0 . \\
00 \\
1\end{array}$ & 1 & $\begin{array}{l}10 . \\
73 \\
0\end{array}$ & $\begin{array}{l}<0 \\
.0 \\
1 \\
\end{array}$ & 1 & $\begin{array}{l}0 . \\
89 \\
7 \\
\end{array}$ & $\begin{array}{l}0 . \\
35 \\
2 \\
\end{array}$ & 1 & $\begin{array}{l}14 . \\
05 \\
2\end{array}$ & $\begin{array}{l}<0 \\
.0 \\
1 \\
\end{array}$ \\
\hline $\begin{array}{l}\text { Micro } \\
\text { habit } \\
\text { at } \times \\
\text { seaso } \\
\mathrm{n}\end{array}$ & 4 & $\begin{array}{l}2 . \\
08 \\
2\end{array}$ & $\begin{array}{l}0 . \\
10 \\
9\end{array}$ & 4 & $\begin{array}{l}2.1 \\
41\end{array}$ & $\begin{array}{l}0.1 \\
01\end{array}$ & 4 & $\begin{array}{l}2.6 \\
37\end{array}$ & $\begin{array}{l}0.0 \\
53\end{array}$ & 4 & $\begin{array}{l}0.2 \\
23\end{array}$ & $\begin{array}{l}0 . \\
92 \\
3\end{array}$ & 4 & $\begin{array}{l}0 . \\
54 \\
3\end{array}$ & $\begin{array}{l}0 . \\
70 \\
5\end{array}$ & 4 & $\begin{array}{l}1.7 \\
59\end{array}$ & $\begin{array}{l}0 . \\
16 \\
1\end{array}$ \\
\hline
\end{tabular}

Table 5.

\begin{tabular}{|c|c|c|c|c|c|c|}
\hline $\begin{array}{l}\text { Respir } \\
\text { ation } \\
\text { rate }\end{array}$ & $15^{\circ} \mathrm{C}$ & $22^{\circ} \mathrm{C}$ & $28^{\circ} \mathrm{C}$ & $34^{\circ} \mathrm{C}$ & $40^{\circ} \mathrm{C}$ & $43^{\circ} \mathrm{C}$ \\
\hline
\end{tabular}




\begin{tabular}{|c|c|c|c|c|c|c|c|c|c|c|c|c|c|c|c|c|c|c|}
\hline $\begin{array}{l}\text { Treatm } \\
\text { ent }\end{array}$ & $\begin{array}{l}d \\
f\end{array}$ & $F$ & $P$ & $\begin{array}{l}d \\
f\end{array}$ & $F$ & $\boldsymbol{P}$ & $\begin{array}{l}d \\
f\end{array}$ & $F$ & $P$ & $\begin{array}{l}d \\
f\end{array}$ & $\boldsymbol{F}$ & $P$ & $\begin{array}{l}d \\
f\end{array}$ & $\boldsymbol{F}$ & $P$ & $\begin{array}{l}d \\
f\end{array}$ & $F$ & $P$ \\
\hline $\begin{array}{l}\text { Microh } \\
\text { abitat }\end{array}$ & 4 & $\begin{array}{l}1.5 \\
37\end{array}$ & $\begin{array}{l}0.2 \\
16\end{array}$ & 4 & $\begin{array}{l}0.3 \\
20\end{array}$ & $\begin{array}{l}0.8 \\
62\end{array}$ & 4 & $\begin{array}{l}0.2 \\
29\end{array}$ & $\begin{array}{l}0.9 \\
20\end{array}$ & 4 & $\begin{array}{l}1.7 \\
38\end{array}$ & $\begin{array}{l}0.1 \\
66\end{array}$ & 4 & $\begin{array}{l}0.9 \\
87\end{array}$ & $\begin{array}{l}0.4 \\
29\end{array}$ & 4 & $\begin{array}{l}0.3 \\
45\end{array}$ & $\begin{array}{l}0.8 \\
44\end{array}$ \\
\hline Season & 1 & $\begin{array}{l}0.0 \\
03\end{array}$ & $\begin{array}{l}0.9 \\
57\end{array}$ & 1 & $\begin{array}{l}0.1 \\
36\end{array}$ & $\begin{array}{l}0.7 \\
15\end{array}$ & 1 & $\begin{array}{l}2.2 \\
42\end{array}$ & $\begin{array}{l}0.1 \\
44\end{array}$ & 1 & $\begin{array}{l}3.3 \\
76\end{array}$ & $\begin{array}{l}0.0 \\
75\end{array}$ & 1 & $\begin{array}{l}1.5 \\
26\end{array}$ & $\begin{array}{l}0.2 \\
26\end{array}$ & 1 & $\begin{array}{l}1.4 \\
12\end{array}$ & $\begin{array}{l}0.2 \\
47\end{array}$ \\
\hline $\begin{array}{l}\text { Microh } \\
\text { abitat } \times \\
\text { season }\end{array}$ & 4 & $\begin{array}{l}0.2 \\
36\end{array}$ & $\begin{array}{l}0.9 \\
16\end{array}$ & 4 & $\begin{array}{l}0.2 \\
79\end{array}$ & $\begin{array}{l}0.8 \\
89\end{array}$ & 4 & $\begin{array}{l}2.7 \\
03\end{array}$ & $\begin{array}{l}<0 . \\
05\end{array}$ & 4 & $\begin{array}{l}0.9 \\
07\end{array}$ & $\begin{array}{l}0.4 \\
71\end{array}$ & 4 & $\begin{array}{l}1.1 \\
72\end{array}$ & $\begin{array}{l}0.3 \\
42\end{array}$ & 4 & $\begin{array}{l}1.5 \\
49\end{array}$ & $\begin{array}{l}0.2 \\
21\end{array}$ \\
\hline
\end{tabular}

Table 6.

\begin{tabular}{llllll}
\hline Season & Microhabitat & $\mathbf{N}$ & Mean $\boldsymbol{A B T}( \pm \mathbf{S E})$ & Min-Max & Range \\
\hline \multirow{5}{*}{ Winter } & $C$ & 5 & $35.3(1.5)$ & $30.3-38.8$ & 8.5 \\
& $N E$ & 6 & $33.3(1.3)$ & $28.4-37.5$ & 9.1 \\
& $F E$ & 4 & $36.1(0.6)$ & $35.1-37.5$ & 2.4 \\
& FE & 7 & $34.2(1)$ & $31.1-36.7$ & 5.6 \\
& SE & 5 & $34.4(0.8)$ & $32.4-37.0$ & 4.6 \\
\hline \multirow{3}{*}{ Summer } & WE & 11 & $36.2(0.7)$ & $30.6-38.8$ & 8.2 \\
& $F R$ & 9 & $37.6(0.5)$ & $35.3-40.6$ & 5.3 \\
& $S E$ & 6 & $36.8(0.6)$ & $34.8-38.4$ & 3.1 \\
& & 6 & $37.3(0.7)$ & $35.7-40.3$ & 4.6 \\
\hline
\end{tabular}




\section{ACCEPTED MANUSCRIPT}

\section{Figure captions.}

Figure 1. Patella vulgata estimated operative temperature during two successive high tides in winter (A) and in summer 2014 (B) on a semi exposed rocky shore (Dellec, $48^{\circ} 21^{\prime} 09 \mathrm{~N}, 4^{\circ}$ 34' $01 \mathrm{~W}$, France) in different microhabitats (C: crevice, white dots; WE: vertical west exposed, light light grey dots; NE: vertical north exposed, light grey dots; FR: flat rock, dark grey dots; SE: vertical south exposed, black dots). Note that no temperature was recorded on WE in summer on that specific low tide.

Figure 2. Patella vulgata estimated operative temperature values recorded over 14 days every 10 minutes in summer 2014 on a semi exposed rocky shore (Dellec, $48^{\circ} 21^{\prime} 09 \mathrm{~N}, 4^{\circ}$ 34' $01 \mathrm{~W}$, France) on south- and north- exposed surfaces (black and grey dots and lines, respectively).

Figure 3. Patella vulgata respiration rates (grey dots) and cardiac activity (black dots) in response to temperature in winter and in summer. Values are means and error bars are $95 \%$ confidence limits. $17<\mathrm{n}_{\text {respiration-winter }}<21,12<\mathrm{n}_{\text {respiration-summer }}<21,20<\mathrm{n}_{\text {cardiac activity-winter }}<$ $21,14<\mathrm{n}_{\text {cardiac activity-summer }}<19$.

Figure 4. Representative examples of Arrhenius plots used to define the Arrhenius Break Temperature $(A B T)$ in Patella vulgata individuals in response to a step-wise ramp of $1^{\circ} \mathrm{C}$ every 10 minutes in laboratory in winter (black dots and line) and in summer (grey dots and line).

Figure 5. Temperatures inducing heat coma (HCTs) in Patella vulgata individuals in response to a step-wise ramp of $1{ }^{\circ} \mathrm{C}$ every 10 minutes in laboratory in winter (black points) and in summer (grey points). Individuals were collected within different microhabitats (C: crevice; NE: vertical north exposed; WE: vertical west exposed; FR: flat rock; SE: vertical south exposed). Each dot represents a $H C T$ value $(25<\mathrm{n}<44$ in winter; $38<\mathrm{n}<43$ in summer). 


\section{ACCEPTED MANUSCRIPT}

Squares indicate the mean $H C T$ obtained in individuals sampled within each microhabitat in both winter and summer.

Figure 6. Thermal safety margins determined for Patella vulgata individuals in different microhabitats (C: crevice; NE: vertical north exposed; WE: vertical west exposed; FR: flat rock; SE: vertical south exposed). TSM was defined as the difference between the HCT measured for each tested individual from a microhabitat and the highest estimated operative temperature recorded within that microhabitat over a 14 day period in summer 2014 . Values are means $( \pm \mathrm{SE}, 38<\mathrm{n}<43) .{ }^{*}: \mathrm{P}<0.05, * *: \mathrm{P}<0.01$. 


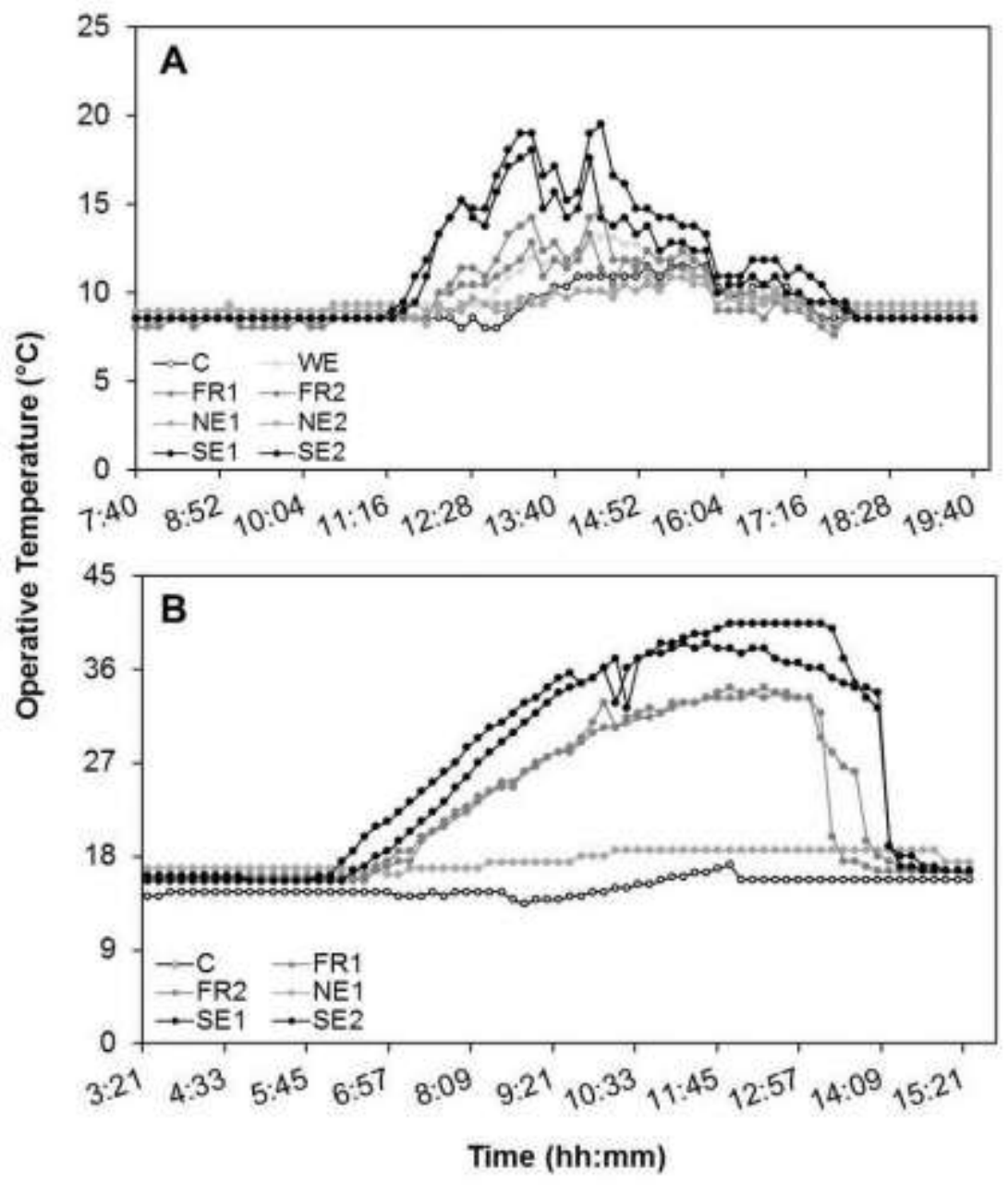

Fig. 1. 


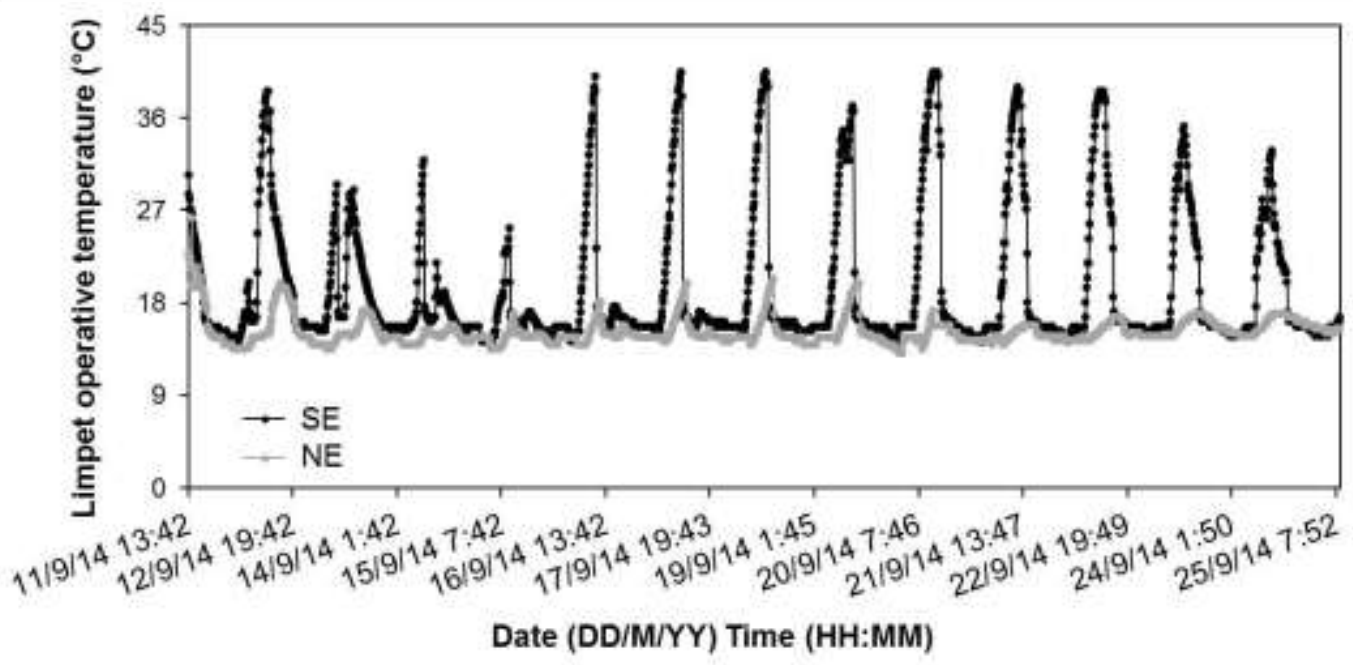

Fig. 2. 


\section{ACCEPTED MANUSCRIPT}

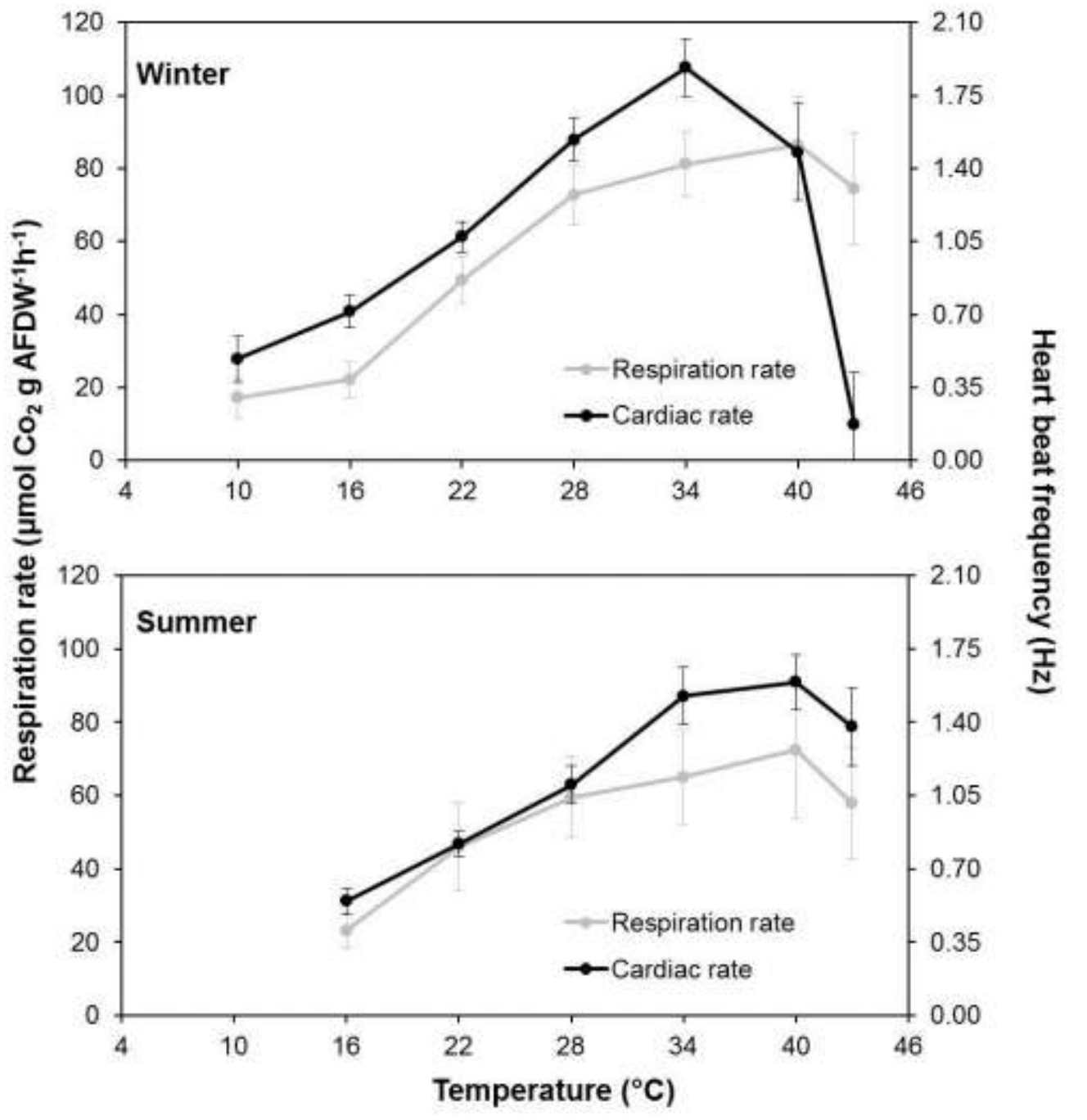

Fig. 3. 


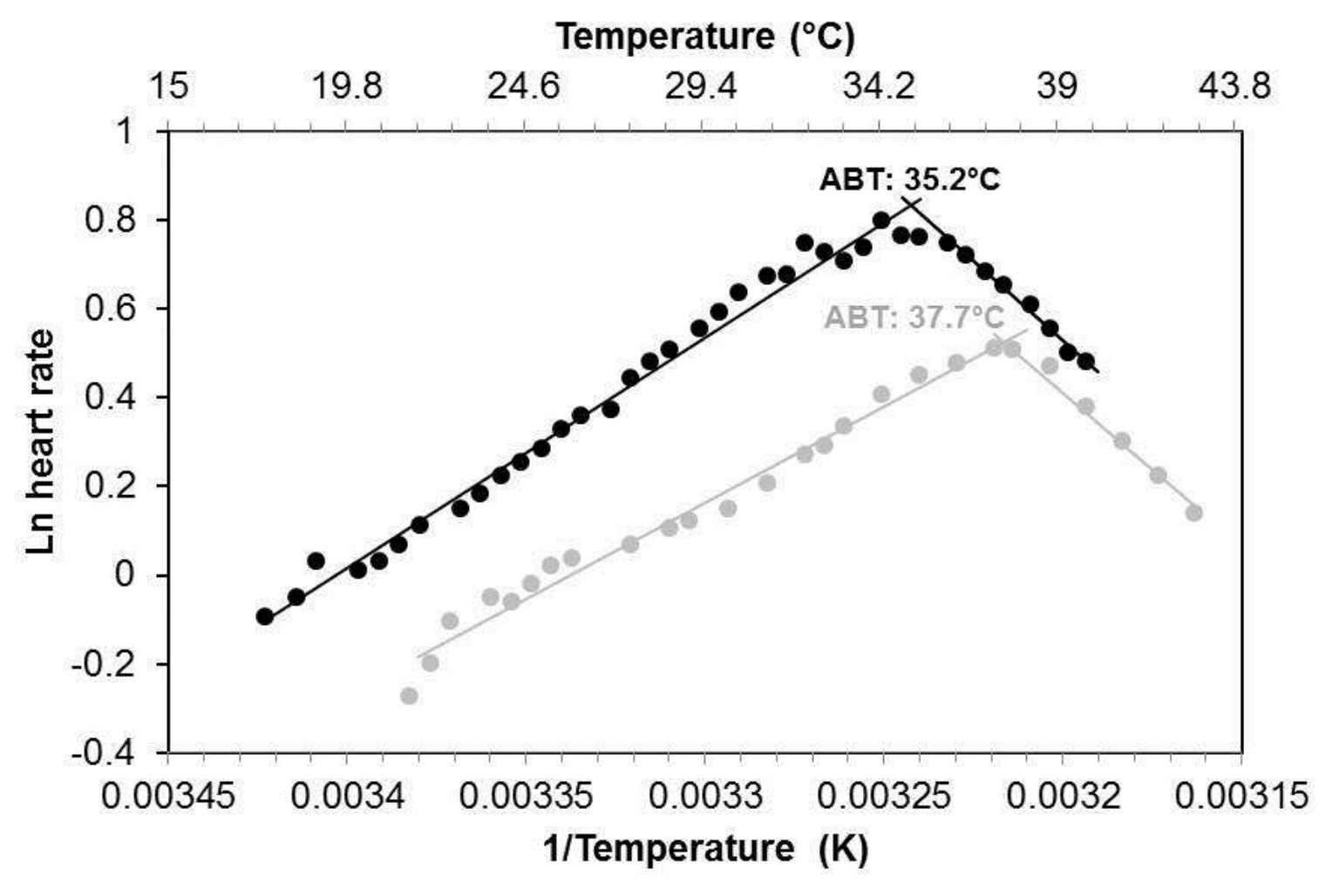

Fig. 4. 


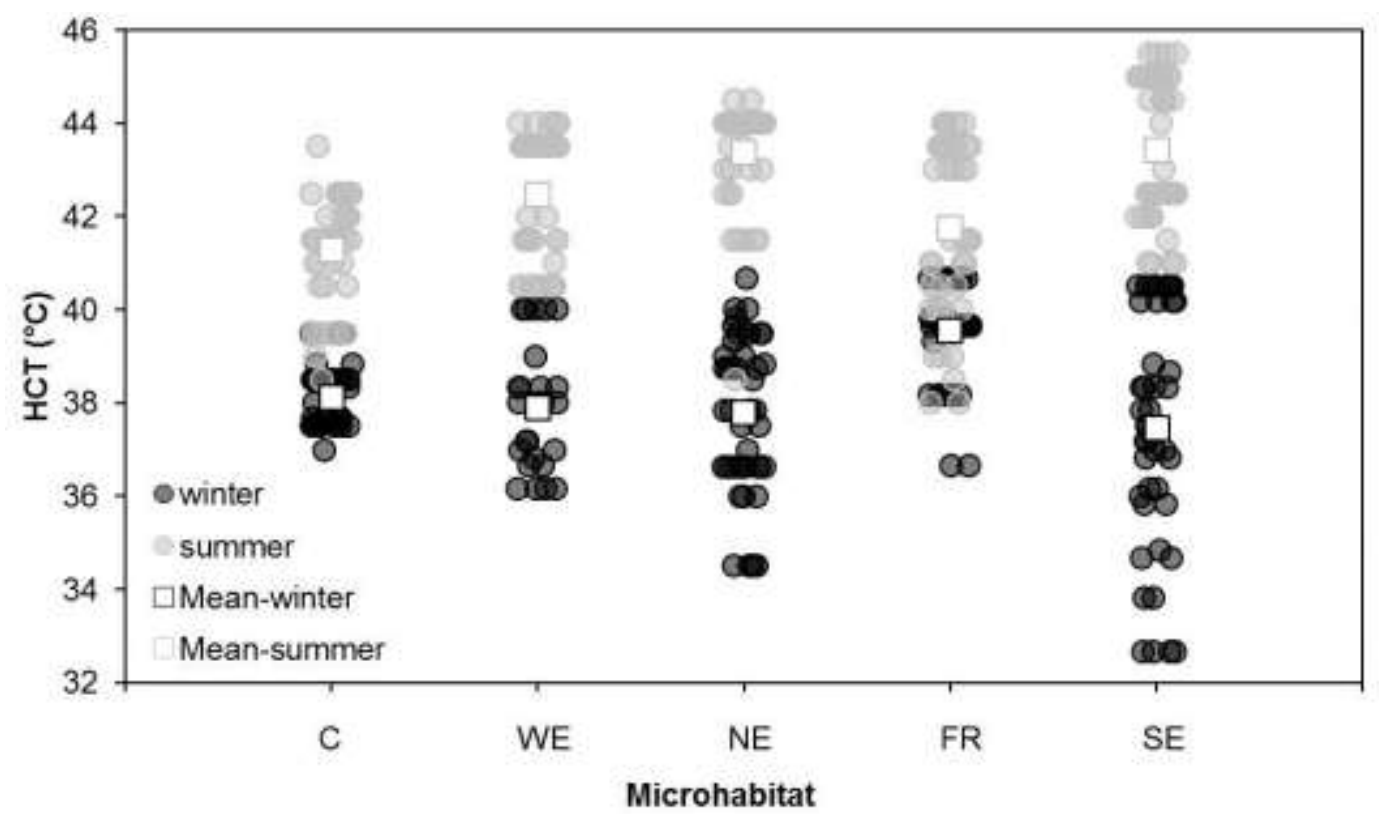

Fig. 5. 


\section{ACCEPTED MANUSCRIPT}

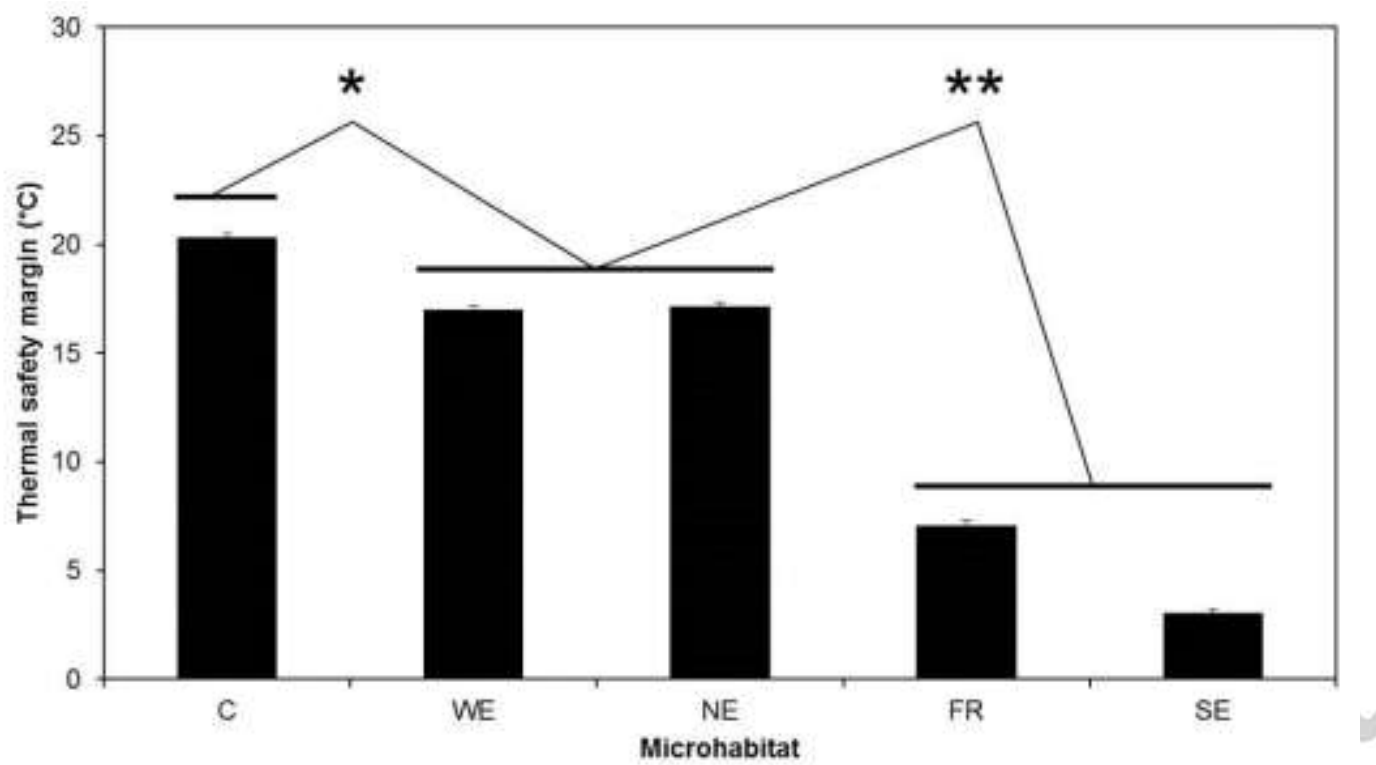

Fig. 6. 